\title{
Acute Peritonitis Generalized at the Koutiala Reference Health Center, Mali: Epidemiological, Etiological and Therapeutic Aspects
}

\author{
Mahamadou Coulibaly ${ }^{1,2 *}$, Birama Togola1,3, Traoré Drissa ${ }^{1,3}$, Bréhima Bengaly ${ }^{1,3}$, \\ Souleymane Sanogo ${ }^{3}$, Drissa Ouattara ${ }^{3}$, Diallo Siaka ${ }^{3}$, Madiassa Konaté1,4, Nouhoum Ongoiba ${ }^{1,3}$ \\ ${ }^{1}$ Faculty of Medicine, University of Science, Technique and Technologies of Bamako, Bamako, Mali \\ ${ }^{2}$ Department of Surgery, Koutiala Hospital, Bamako, Mali \\ ${ }^{3}$ Department of Surgery, University Hospital Center Point G, Bamako, Mali \\ ${ }^{4}$ Department of General Surgery, CHU Gabriel Touré, Bamako, Mali \\ Email: *cmahamadou38@yahoo.fr
}

How to cite this paper: Coulibaly, M., Togola, B., Drissa, T., Bengaly, B., Sanogo, S., Ouattara, D., Siaka, D., Konaté, M. and Ongoiba, N. (2020) Acute Peritonitis Generalized at the Koutiala Reference Health Center, Mali: Epidemiological, Etiological and Therapeutic Aspects. Surgical Science, 11, 111-116.

https://doi.org/10.4236/ss.2020.116014

Received: April 26, 2020

Accepted: June 9, 2020

Published: June 12, 2020

Copyright $\odot 2020$ by author(s) and Scientific Research Publishing Inc. This work is licensed under the Creative Commons Attribution International License (CC BY 4.0).

http://creativecommons.org/licenses/by/4.0/ (c) (i) Open Access

\begin{abstract}
History: In Mali, several studies have been carried out on acute peritonitis but in the Koutiala circle it is a first. Aim: To evaluate the epidemiological, etiological and therapeutic aspects of generalized acute peritonitis at the Koutiala reference health center. Method: This was a 14-month prospective and descriptive study from August 1, 2017 to November 30, 2019, covering all patients admitted and operated for generalized acute peritonitis. The parameters studied were age, sex, frequency, clinical aspects, etiologies, treatment and postoperative operations. Result: The number was 93 cases, 72 men and 21 women. The average age was 34.2 years (Extremes: 2 - 75 years). The hospital frequency was $2.0 \%$. The incidence rate of generalized acute peritonitis in the circle was 12.4 cases per 100,000 population. The clinical picture was still of peritonitis. The Widal-Félix serology was positive in 19 cases. Perioperative bacteriological sampling was systematic. The etiologies were dominated by digestive perforations in 81 cases $(87 \%)$ of which 33 were located at the ileal level, postoperative peritonitis ( 6 cases) and ruptured pyocholecyst ( 2 cases). There were also 3 cases of primary peritonitis and 1 case of gynecological peritonitis. Excision-suturing was the most used surgical technique with $35.5 \%(\mathrm{n}=33)$. Postoperatively, we identified 10 cases of parietal suppuration (10.8\%), 6 cases of postoperative peritonitis (6.5\%), 2 cases of external digestive fistula (2.2\%) and 7 cases of death (7.5\%). Conclusion: Acute peritonitis occupies second place in abdominal surgical emergencies in the Koutiala circle. The etiologies are multiple and varied and are dominated by the ileal perforation which is secondary to typhoid fever more often. In most
\end{abstract}


cases the surgical treatment is done by excision-suturing of the perforation.

Mortality and morbidity remain high.

\section{Keywords}

Generalized Acute Peritonitis, Emergency, Koutiala

\section{Introduction}

Acute peritonitis is the acute inflammation of the peritoneum by septic inoculation most often from an intraperitoneal organ and more rarely after general contamination [1]. Acute peritonitis is a frequent abdominal surgical emergency. This frequency is 3\% in France [2], 7.2\% in Mali [1] and 28.8\% in Niger [3]. The positive diagnosis is evoked in front of the digestive signs (abdominal pain, vomiting, loss of materials and gas, hiccups), fever, biological, ultrasound, CT and $\mathrm{X}$-ray signs of the abdomen without preparation [4]. Digestive perforations are the most frequent. The etiologies are dominated by typhoid fever followed by complicated appendicitis [5]. Treatment is based on surgery (digestive stoma, or suturing of the perforation and or anastomosis resection, washing and drainage of the abdominal cavity) associated with resuscitation and antibiotic therapy [3]. The prognosis costs from the earliest diagnosis and management. In Mali, several studies have been carried out on acute peritonitis but in the Koutiala circle it is a first whose aim was to assess the epidemiological, etiological and therapeutic aspects of generalized acute peritonitis at the Koutiala reference health center.

\section{Methodology}

This was a 14-month prospective and descriptive study from August 1, 2017 to November 30, 2019. It focused on all patients admitted and operated for generalized acute peritonitis in the general surgery department of the reference health center from Koutiala. Unoperated patients were not included. The comparison test used was the Chi-square test and the significance of the difference was determined by a probability $\mathrm{p}<0.05$. The realization of this work required a detailed data base, we used for that the medical file of the patients, the register of consultation, the notebooks of the operational report. The parameters studied were age, sex, frequency, clinical aspects, etiologies, treatment and postoperative treatment.

\section{Result}

The number was 93 cases, 72 men and 21 women. The average age was 34.2 years (Extremes: 2 - 75 years). Compared to the activities of the department, generalized acute peritonitis represented $2.03 \%$ of consultation $(n=4581), 10.8 \%$ of surgical procedures $(n=864)$ and $26.2 \%$ of surgical emergencies $(n=355)$. It is the second cause of acute surgical abdomens in the department after acute 
appendicitis. The incidence rate of generalized acute peritonitis in the circle was 12.4 cases per 100,000 population. Clinically all presented with diffuse abdominal pain $(n=100)$. Associated signs were vomiting in $91.3 \%$ of cases $(n=85)$, cessation of materials and gases $(64.5 \% ; n=60)$ and fever $(91.3 \% ; n=85)$. The mean duration of development of symptoms before the consultation was $6.2 \pm$ 4.3 days (Extremes: 1 - 30 days). From a biological point of view, neutrophilic polynuclear hyperleukocytosis was found in 87 patients, i.e. $93.5 \%$ of cases. The abdominal X-ray without preparation was done in 64 patients $(68.8 \%)$. He had pneumoperitoneum in $43.0 \%$ of cases $(n=40)$, diffuse greyness in $16.1 \%$ of cases $(\mathrm{n}=15)$ and hydro-aeric levels in $5.4 \%$ of cases $(\mathrm{n}=5)$. Abdominal ultrasound revealed 29 patients $(31.2 \%)$ with intraperitoneal effusion. The Widal-Félix serology was positive in 19 cases and all of these patients had ileal perforation. All our patients underwent pre and per operative resuscitation, the minimum duration of which was 2 hours, which consisted of rehydration, analgesic and probabilistic antibiotic therapy. The operation was done urgently in all patients. The xypho-pubic approach was the most used with $88.2 \%$ of the cases $(n=82)$. The etiologies are listed in (Table 1). The 81 cases of digestive perforations (87.3\%) were located at the ileal level in 34 patients (36.6\%); they were unique 69 times, double 9 times and multiple 3 times. The 6 cases of postoperative peritonitis were secondary to lose sutures or anastomosis in 4 patients and residual phrenic effusion in 2 patients. Primary peritonitis was due to infected axitis (2 cases) and infected hemoperitoneum ( 1 case). The therapy was excision-suturing in $35.5 \%$ of cases $(n=33)$, resection-anastomosis $(16.1 \% ; n=15)$, digestive stoma $(9.7 \%$; $\mathrm{n}=9)$, appendectomy $(32.2 \% ; \mathrm{n}=30)$ and cholecystectomy $(2.2 \%, \mathrm{n}=2)$. The peritoneal cavity and simple drainage were performed in 4 patients $(4.3 \%)$. The direct examination of the sample of the peritoneal effusion was positive in 72 cases $(77.4 \%)$, sterile in 21 cases $(22.6 \%)$. He revealed gram-negative bacilli in 53 cases (57\%) (Table 2). Probabilistic antibiotic therapy was double antibiotic therapy in 72 cases $(77.4 \%)$. It was a combination of ceftriaxone and

Table 1. Distribution of patients operated for generalized acute peritonitis in Koutiala between August 2017 and December 2019 according to etiologies.

\begin{tabular}{ccc}
\hline Types & Number of cases & $\%$ \\
\hline Duodenal perforation & 6 & 6.5 \\
Gastric perforation & 10 & 10.8 \\
Ileal perforation & 34 & 36.6 \\
Appendicular perforation & 26 & 28.0 \\
Caecal perforation & 5 & 5.4 \\
Ruptured pyocholecyst & 2 & 2.2 \\
Gynecological peritonitis & 1 & 1.1 \\
Primary peritonitis & 3 & 3.2 \\
PPO & 6 & 6.5 \\
Total & 93 & 100.0 \\
\hline
\end{tabular}


Table 2. Distribution of patients operated for generalized acute peritonitis in Koutiala between August 2017 and December 2019 according to the result of the intraperitoneal effusion sample.

\begin{tabular}{ccc}
\hline Result & Number of cases & $\%$ \\
\hline Bacillus gram negative & 53 & 57.0 \\
Gram positive shell & 8 & 8.6 \\
Bacillus gram- and shell gram+ & 11 & 11.8 \\
Sterile direct examination & 21 & 22.6 \\
Total & 93 & 100.0 \\
\hline
\end{tabular}

metronidazole. It was a triple antibiotic therapy in 21 cases $(22.6 \%)$ with the combination of gentamycin. The average duration of parental antibiotic therapy was 3 days ( 3 and 7 days). Oral exit antibiotic therapy was the combination of amoxicillin and metronidazole in 72 cases $(77.4 \%)$ and the combination of amoxicillin and clavulanic acid in 21 cases (22.6\%). The postoperative follow-up was simple in 70 patients or $75.3 \%$ of the cases. We identified 10 cases of parietal suppuration (10.8\%), 6 cases of postoperative peritonitis (6.5\%), 2 cases of external digestive fistula (2.2\%) and 7 cases of death (7.5\%). These deaths were due to multi-lateral failure in 2 cases, septic shock in 2 cases and hypovolemic shock in 3 cases.

\section{Threads}

This prospective study, which involved 93 cases of generalized acute peritonitis, was limited by the inadequacy of the technical platform and the low income of the patients. However, the quality of the results obtained with the acts performed deserves to be supported and encouraged. Generalized acute peritonitis affected men much more with a sex ratio of 3.4 and a younger population (average age of 34.2 years). Considered a frequent surgical emergency, it occupies the second cause of acute abdomens after appendicitis with a frequency of $26.2 \%$ at the reference health center and an incidence rate of 12.4 cases per 100,000 inhabitants in the circle of Koutiala. The delay in consultation is the explanation for this high frequency of peritonitis with an average duration of evolution of the symptomatology before the consultation of $6.2 \pm 4.3$ days (Extremes: 1 - 30 days); and this delay is very often secondary to certain traditional medicine practices but also to diagnostic errors at the initial consultation carried out in community health centers and private clinics. Several African studies bear witness to these observations [3] [6]. In most cases the peritonitis was secondary. Digestive perforations were the main etiologies with $87.3 \%$ of cases. The location of these perforations was ileal in $36.6 \%$ of the cases. Ileal perforations were most often secondary to typhoid fever. Similar results are provided by Sambo in Benin $(52.8 \% \mathrm{p}=0.7)$ [7] and Ouangré in Burkina Faso (42.5\% $\mathrm{p}=0.5)$ [8]; and this would be linked directly to the non-respect of the hygienic conditions of the population and indirectly to the low economic levels of our countries. Our re- 
sults are in contradiction with those of $\mathrm{N}$ go Nonga in Cameroon [9] and Rakotomavo in Madagascar [10] where duodenal and gastric perforations lead the etiologies with respectively $46.3 \%$ and $69.2 \%$ of cases. This would be closely linked to an increased incidence of ulcerative disease in their slightly older population. There were also 6 cases of postoperative peritonitis, the initial procedures of which were performed either by general practitioners or by non-visceral surgeons. This is an opportunity to draw the attention of health policy-makers to the capacity-building of referral health centers in circles by specialists. The 3 cases of primary peritonitis were due to infected axitis ( 2 cases) and infected hemoperitoneum (1 case). At present, the primary use of laparoscopy remains important in certain indications of peritonitis as evidenced by the study by Gauzit et al. in France with an average of 26\% laparoscopy in the management of peritonitis [11]. For lack of this therapeutic arsenal, all our patients were operated on by laparotomy. Excision-suturing was the most used technique with 35.5\%. This rate is lower than that provided by Kassegne [12] which is $54.5 \%(\mathrm{p}=0.01)$. This difference is linked to the fact that his study focused only on peritonitis by typhic perforation of the small intestine. The postoperative antibiotic therapy was based on the result of the direct examination of the sample of the peritoneal effusion because the antibiogram is not feasible in our circle. It was double antibiotic therapy in $77.4 \%$ of cases and triple antibiotic therapy in $22.6 \%$ of cases. We recorded $19.3 \%$ of morbidity cases and $7.5 \%$ of mortality cases. These results are close to those of the literature [9] [13] [14].

\section{Conclusion}

Acute peritonitis occupies second place in abdominal surgical emergencies in the Koutiala circle. The etiologies are multiple and varied and are dominated by the ileal perforation which is secondary to typhoid fever more often. In most cases the surgical treatment is done by excision-suturing of the perforation. Mortality and morbidity remain high.

\section{Author Contributions}

All authors have read and approved the final version of the manuscript.

\section{Original Article}

The article submitted is an original work which is not considered or revised by another publication, and has not been published elsewhere.

\section{Conflicts of Interest}

The authors do not declare any conflict of interest.

\section{References}

[1] Kanté, L., Diakité, I., Togo, A., Dembélé, B.T., Traoré, A., Maiga, A., Samaké, A., Samaké, H., Keita, M., Traoré, I. and Diallo, G. (2013) Péritonites aiguës généra- 
lisées à l'hôpital Somine Dolo de Mopti: aspects épidémiologique et thérapeutique. Mali Medical, 28, 20-23.

[2] Lorand, I., Molinier, N. and Sales, J.P. (1999) Résultats du traitement coelioscopique des ulcères perforés. Journal de Chirurgie (Paris), 124, 149-153. https://doi.org/10.1016/S0001-4001(99)80057-9

[3] Harouna, Y.D. (2001) Deux ans de chirurgie digestive d'urgence à l'hôpital national de Niamey (Niger): Etude analytique et pronostique. Médecine Afrique Noire, 48, 49-54.

[4] Mondor, H. (1965) Urgent Diagnosis-Abdomen. Masson, Paris, 1-31.

[5] Harouna, Y.D., Abdou, I., Saidou, B. and Bazira, L. (2001) Les péritonites en milieu tropical: Particularités étiologiques et facteurs pronostiques actuels-A propos de 160 cas. Médecine Afrique Noire, 48, 104-106.

[6] Gaye, I., Leye, P.A., Traoré, M., Ndiaye, P.I., Ba, E.H.B. and Diawo, M. (2016) Prise en charge péri opératoire des urgences chirurgicales abdominales chez l'adulte au CHU Aristide Le Dantec. Pan African Medical Journal, 24, 190. https://doi.org/10.11604/pamj.2016.24.190.9929

[7] Sambo, B.T., et al. (2017) Prise En Charge Des Péritonites Aiguës Dans Un Hôpital De District En Afrique Sub-saharienne: Cas Du Bénin. European Scientific Journal, 13, 388-395. https://doi.org/10.19044/esj.2017.v13n36p388

[8] Ouangre, E., Zida, M., Bonkoungou, P.G., Sanou, A. and Traore, S. (2013) Les Péritonites aigües généralisées en milieu rural au Burkina Faso: à propos de 221 cas. Revue Cames Santé, 1, 75-79.

[9] Ngo Nonga, B., Mouafo Tambo, F., Ngowe Ngowe, M., Takongmo, S. and Sosso, M.A. (2010) Etiologiesdes péritonites aigues généralisées au CHU de Yaoundé. Revue Africaine de chirurgie et spécialité, 4, 30-32. https://doi.org/10.4314/racs.v4i7.66378

[10] Rakotomavo, F.A., Riel, A.M., Rakotoarison, R., Randrianambinina, H., Randrianambinina, T. and Randriamiarana, M.J. (2012) Péritonite aigüe: aspects épidémio-clinique et étiologique dans un service des urgences chirurgicales malgache. A propos de 60 cas. Journal Africain d'Hépato-Gastroentérologie, 6, 33-37. https://doi.org/10.1007/s12157-011-0355-2

[11] Gauzit, R., Pean, Y., Barth, X., Mistretta, F. and Lalaude, O. (2009) Epidemiology Management, and Prognosis of Secondary Non-Postoperative Peritonitis: A French Prospective Observational Multicenter Study. Surgical Infections, 10, 119-127. https://doi.org/10.1089/sur.2007.092

[12] Kassegne, I., Sewa, E.V., Kanassoua, K., Alassani, F., Adabra, K., Amavi, A.K., et al. (2016) Aspects diagnostiques, thérapeutiques et pronostiques des perforations typhiques du grêle à Dapaong, Togo. Médecine et Santé Tropicales, 26, 71-74. https://doi.org/10.1684/mst.2016.0544

[13] Dieng, M., Ndiaye, A., Ka, O., Konaté, I., Dia, A. and Touré, C.T. (2006) Aspects étiologiques et thérapeutiques des peéitonites aiguës généralisees d'origine digestive. Une série de 207 cas opérés en cinq ans. Mali Medical, 21, 47-51.

[14] Kambiré, J.L., Zaré, C., Sanou, B.G. and Kambou, T. (2017) Étiologies et pronostic des péritonites secondaires au centre hospitalier universitaire de Bobo-Dioulasso (Burkina Faso). Journal Africain d'Hépato-Gastroentérologie, 10, 119-123. https://doi.org/10.1007/s12157-017-0719-3 